\title{
Space and Polity
}

\section{Irish enough: changing narratives of citizenship and national identity in the context of Brexit}

\section{Patricia Burke Wood \& Mary Gilmartin}

To cite this article: Patricia Burke Wood \& Mary Gilmartin (2018) Irish enough: changing narratives of citizenship and national identity in the context of Brexit, Space and Polity, 22:2, 224-237, DOI: 10.1080/13562576.2018.1543824

To link to this article: https://doi.org/10.1080/13562576.2018.1543824

\section{Published online: 16 Nov 2018.}

Submit your article to this journal $\sqsubset$

山 Article views: 584

Q View related articles $\asymp$

View Crossmark data \lceil

4 Citing articles: 1 View citing articles 


\title{
Irish enough: changing narratives of citizenship and national identity in the context of Brexit
}

\author{
Patricia Burke Wood (D) ${ }^{a}$ and Mary Gilmartin ${ }^{b}$ \\ ${ }^{\mathrm{a} D e p a r t m e n t ~ o f ~ G e o g r a p h y, ~ Y o r k ~ U n i v e r s i t y, ~ T o r o n t o, ~ O N, ~ C a n a d a ; ~}{ }^{\mathrm{b}}$ Department of Geography, Maynooth \\ University, Maynooth, Co. Kildare, Ireland
}

\begin{abstract}
This paper is a preliminary investigation of Irish identity and citizenship in the aftermath of the decision of the UK to leave the European Union. It identifies three significant impacts: the marked increase in applications for citizenship in the Republic of Ireland from residents of Northern Ireland and Britain and the justifying narratives for those applications; the respondent narratives in the Republic about what it means to be Irish; and the effects on ideas of Ireland as an all-island identity. We consider the ways in which access to Irish citizenship is bordered by narratives of ethnic belonging and draw attention to how Irish citizenship is 'bordered' in the newsmedia. Through an examination of newsmedia and social media representations of and explanations for the post-Brexit rise in applications, we explore the interrelationship between strategic and affective aspects of citizenship and national identity and the possibilities of a resurgence of Irish ethnic nationalism post-Brexit. Through this case study, we aim to signal critical sites of change and frameworks of analysis for ongoing study of the specific situation of the island of Ireland as well as the practice of citizenship in the shifting geopolitics of the early twenty-first century more broadly.
\end{abstract}

\section{KEYWORDS}

Ireland; citizenship; Brexit; Northern Ireland; passports

\section{Introduction}

On June 24, 2016, the United Kingdom (UK) of Great Britain (GB) and Northern Ireland (NI) voted in a referendum in support of leaving the European Union (EU). In England and Wales, the majority vote was for Leave; in Scotland and NI (with a vote of $55.8 \%$ Remain/44.2\% Leave), the majority vote was for Remain. The consequences of the Brexit vote will be far-reaching, with likely effects on economic activity, politics, and mobility. One of the immediate consequences, apparent the day after the Brexit vote, is a significant increase in the numbers of British people exploring the options, and applying, for citizenship of other EU countries (Harding, 2016).

The uncertainties about Brexit pose specific challenges for social scientists interested in the vote and its consequences. There is some analysis of the reasons for the vote to leave the EU, suggesting it was supported primarily by those who are economically, politically and socially 'left behind' (Becker, Fetzer, \& Novy, 2017; Goodwin \& Heath, 2016). 
However, work on the likely consequences is more empirically and theoretically speculative, often directed towards the processes of negotiation and policy-making (see, for example, Cassidy, Innocenti, \& Bürkner, 2018; Hayward, 2018). The meanings of Brexit remain out of focus, and difficult for social scientists to capture and ground. For this reason, our paper addresses the rise in applications for EU citizenship, specifically citizenship in Ireland, as a material and observable consequence of the Brexit vote. We do this through an analysis of newsmedia and social media representations of the phenomenon. We thus examine 'both sides' of the dynamic exchange between newsmedia, which may reflect particular positions of political, social and economic elites, and social media, whose public reach may be similar but whose access is more open to 'ordinary people.' While our study is preliminary, this approach provides a more comprehensive examination of immediate reactions to and commentary on unfolding events that may reflect and produce broader public opinion (Hepp \& Krotz, 2014; Waisbord, 2014).

Since the Brexit decision, its likely impacts on Ireland have been receiving considerable attention, with Ireland and its future central to negotiations over UK withdrawal. Areas of concern include the border and cross-border co-operation, economic consequences, potential challenges to the peace process, and the future of the Common Travel Area (Hayward, 2018). These concerns are unresolved, ongoing, and in constant flux. In contrast, the tangible rise in applications for Irish passports by British people has been reported on but received limited critical attention. We argue that the rush to Irish citizenship provides important insights into how Ireland and Irish identity is understood and constructed, in the process exposing the multiscalarity of nation and citizenship. Drawing on the work of Smith (2001, 2008), Isin (2007) and Ong (1999, 2006), who have argued that citizenship is flexible, strategic and spatially complex, we take a critical and geographic approach to Irish citizenship that recognizes the ways in which belongings and political rights in practice may reinforce, transgress and reimagine the boundaries of formal territories.

In the paper, we begin by outlining the historically complex nature of Ireland and Irishness. We next outline our research on applications for Irish citizenship in the period following the Brexit vote, providing details of how we identified, categorized and analyzed media reports. We then discuss the ways in which Ireland and Irishness are discursively constructed in media reports, particularly by those who are, or are considering, applying for Irish citizenship. In our conclusion, we discuss the broader implications of the rush to Irish citizenship for how we understand Ireland, Irishness, and the nature of belonging in the post-Brexit era.

\section{The multiple meanings of Ireland and Irish}

The 'Irish nation' is, geographically speaking, several things: the Republic of Ireland, the island of Ireland, and the Irish diaspora, particularly its most recent emigrants. The Republic is the Irish nation-state, but Northern Ireland is often included in 'Ireland.' This in not merely a romantic, imagined notion (although that would be significant in and of itself); the Ireland that includes Northern Ireland is a practiced one, with international recognition. Indeed, for over 60 years the Constitution of Ireland explicitly claimed Northern Ireland as part of its territory, and its claim that the entire island is the 'Irish nation' is acknowledged in the GFA. 
An all-island Ireland exists in many articulations, from political republicanism to a single electricity market, with many cultural and political manifestations in between. The Gaelic Athletic Association (GAA) operates on an all-island basis, with clubs in both the ROI and NI, and is a significant source of national identity. The GAA describes itself explicitly as anti-sectarian and anti-racist. Its final championships are 'all-Ireland' tournaments, and include representatives from all 32 counties on the island of Ireland, as well as teams from London and New York. Similarly, Ireland is represented in international sports, including the Olympics and rugby football, by individuals and teams from the entire island (see, for example, Cronin, 2003; Hunt, 2015).

These connections between the Republic and NI are multiplied by the relationship with the rest of the UK. The Common Travel Area (CTA) between Britain and Ireland was established in the wake of the declaration of the Irish Free State in 1922, when the UK recognized the island as a Dominion within the British Commonwealth. With a minor exception during World War II, there has been no formal immigration control among the UK, the ROI, the Isle of Man and the Channel Islands. The UK's assertion of the Irish Free State as a Dominion made Irish citizens, in the eyes of British law, British subjects, and the UK recognized Irish citizenship only for those present in the Irish Free State (Ryan, 2001).

In its 1948 Republic of Ireland Act, Ireland declared itself a republic and not a Dominion of the British Commonwealth. In 1949, Ireland's claim on NI residents as citizens under Irish law initially deprived them of British citizenship. The UK's 1949 Republic of Ireland Act clarified that those UK residents could claim British citizenship. Those born in the Republic but now living in NI could also claim British citizenship, if they did not claim Irish citizenship. The 1949 act also gave singular authority to the NI Parliament to choose reunification with the Republic. While the 1949 Act formally withdrew the Republic from the Commonwealth, it nevertheless decreed that Ireland would not be treated as a 'foreign country' and maintained the same rights for Irish citizens as those of Commonwealth countries, including the right to immigrate. Ireland's immigration laws have similarly privileged British nationals to provide them rights to entry and residence. The UK's 1983 Representation of the People's Act gave Irish residents in the UK the right to vote, a practice which was reciprocated by Ireland in 1985 (Ryan, 2001).

The 1985 Anglo-Irish Agreement created the Anglo-Irish Intergovernmental Conference and Council, which was replaced in the GFA with British-Irish Intergovernmental Conference, the British-Irish Intergovernmental Council, and an expanded BritishIrish Interparliamentary Body. The GFA also provided for the development of a joint parliamentary forum of the NI Assembly and the Oireachtas (the Irish Parliament), and in 2012, the North/South Inter-Parliamentary Association was created. These and other joint bodies are forums for discussion and oversight of a large and wide variety of portfolios, including: economic development, language policy, transport, agriculture, education, health, the environment, tourism, border security, policing and criminal justice, and relations with the EU (McGarry \& O'Leary, 2006a). In both formal, political practices and institutions, and in social practices, NI has a significant history of consociational and 'bi-national' Irish identities, in which the Republic is an active participant.

The GFA also integrated the EU into the governance of NI. The Organization for Security and Co-operation in Europe has supported the creation of local civil rights legislation, and the European Court of Human Rights is designated as a third-party arbiter of rights 
disputes (McGarry \& O’Leary, 2006a, p. 54). In January 2017, the Irish EU Commissioner Phil Hogan noted that 'The European Commission has a vested interest in protecting the Good Friday Agreement and the success it has been in bringing peace to the island of Ireland since 1998' (Downing, 2017).

Furthermore, nationalist narratives have been a strong part of Ireland's participation in European institutions. Its membership in the European Economic Community (EEC) reduced the significance of the UK for Ireland in several ways, as it looked to move beyond its colonized history, improve its economy and diversify its international relationships (Laffan \& O’Mahony, 2008). In Ireland, "Europe” is at times a concept and other times a context, but in all cases it serves to validate a national narrative or project' (Hayward, 2010, p. 167). As Hayward has further argued, 'Ireland's accession to the EEC in 1973 was presented as the fulfillment and enrichment of Irish national sovereignty, and the 'unsettled existence of Northern Ireland' was one key issue where Ireland hoped its European membership would assist (Hayward, 2010, p. 178). Ireland regularly polls strongly on positive or optimistic feelings towards Europe, the EU and EU policy (see, for example, Smyth, 2018).

The definition and practice of 'Irish,' therefore, was already interwoven with relationships with the UK and the EU prior to the Brexit vote, in both conflictual and cooperative ways. These relationships continue into the Brexit discussions; the UK Government's February 2017 paper to Parliament expressed a commitment to 'maintain' the 'special status' of Irish citizens - who are not considered 'foreigners' - in a post-Brexit UK, although the details of this remain unclear (HM Government, 2017, p. 74). Meanwhile, Ireland has endorsed the EU's position in Brexit negotiations, and EU leaders have declared their support in return, such as Michel Barnier declaring unequivocally that 'Irish issues are EU issues' (Reuters, 2017).

The complexities of governance on the island of Ireland, between the UK and the Republic, and within the EU had already enabled fluid and cosmopolitan practices of Irishness and Irish citizenship; however, there were and are ethnic nationalist tendencies as well. Brexit has both opened up and closed off these different meanings of Irishness, not least because of how it has reshaped the meaning and utility of Irish citizenship for British subjects. Newsmedia reports provide an important and timely insight into how Irishness is being discursively constructed in the post-Brexit era. In the next section, we outline how we identified and categorized newsmedia reports on the rush to Irish citizenship.

\section{Project and method}

In this project, we used secondary data - including media reports, social media activity, and government press releases - to chart the increasing number of applications for Irish passports, and to consider explanations for and reactions to this new phenomenon. We deliberately chose to focus on secondary data in order to listen in on the public conversation on the meanings of Ireland and Irishness in the post-Brexit era. Rather than recruiting participants for qualitative study, we examined how the debate about Irish citizenship was playing out in public, where it has impact and influence. Our interest was in the attitudes and opinions of people who were mobilized on this issue for their own reasons, whether those were personal or professional. 
We approached this in a number of ways. We conducted a search of British and Irish national newspaper reports over the 19-month period from 1 June 2016 to 31 December 2017, covering the period from immediately before the Brexit referendum. We used the LexisNexis database and the search term 'Irish passport' to identify news reports, features, opinion columns and letters that mentioned Irish passports. We chose to focus on two LexisNexis sources: UK nationals (20 sources) and Irish publications (58 sources). While the Irish publications category includes both national and local sources, our search uncovered predominantly accounts in national sources. For comparison with UK sources, we have not included local sources in our discussion of Irish media reports. Significantly more articles in Irish newspapers mentioned Irish passports in this period (417, as opposed to 287 in British newspapers). There was also a higher proportion of opinion and feature columns in Irish newspapers $(24 \%$, in contrast to $17 \%$ in British newspapers). Many of the articles were brief, repeated reports on the numbers of applications for passports, clearly linked to press releases that had been issued by the Department of Foreign Affairs and Trade in Ireland. Others focused specifically on the increase in applications for Irish passports from Northern Ireland, and on the meaning of this for the future of Northern Ireland. A small number - often features - looked at the decisions or plans of individuals - often celebrities - in more detail.

We also categorized the main focus of the media reports in both Ireland and the UK in this period. A summary is provided in Table 1. The main focus of reports included the numbers of passport applications, the impacts of Brexit, and discussions of the meaning of Irish identity and/or citizenship. The proportion of media reports on each of these topics was roughly similar in both Irish and UK media publications. The 'Other' category included reports of the relationship between genuine and fake Irish passports and acts of crime, fraud or terror, many of which were reports in different media publications on the same topic. We also considered the media publications with the highest number of mentions of the term 'Irish passport'. In the UK, these were The Sun (58), Sunday Times (42), Daily Mirror and Independent (33 each), Times and Guardian (27 each). In Ireland, these were Belfast Telegraph (104), Irish Times (86), Irish News (60), Irish Independent (40) and Irish Daily Mail (32). Of these, the Belfast Telegraph and Irish News are published in Belfast, while the Irish Times, Irish Independent and Irish Daily Mail are published in Dublin.

There was a lot of self-generated discussion of borders, passports and Irish citizenship. We also sought and found discussion in the comments on articles, blogs, podcasts, and social media conversations, and in the results of online searches for 'why I applied for an Irish passport.' Newsmedia themselves sought out similar individual stories and we reviewed their results as well. For example, The Guardian put out a call in August

Table 1. Main focus of media reports featuring the term 'Irish passport' in Irish and UK media publications, 1 June 2016 to 31 December 2017.

\begin{tabular}{lcc}
\hline Focus & Irish & UK \\
\hline Passport applications & $129(30.9 \%)$ & $96(33.4 \%)$ \\
Brexit & $127(30.5 \%)$ & $88(30.7 \%)$ \\
lrish identity/citizenship & $107(25.7 \%)$ & $75(26.1 \%)$ \\
Voting rights & $15(3.6 \%)$ & $3(1.0 \%)$ \\
Other & $39(9.4 \%)$ & $25(8.7 \%)$ \\
Total & 417 & 287 \\
\hline
\end{tabular}


2015, almost a full year before the referendum, asking readers whether they were thinking of moving or getting a passport in another EU country in anticipation of the result. They heard from over 1,500 people, 700 of whom wrote after the referendum.

Our review of over 1,000 media reports on Irish passports and related Ireland-Brexit issues, and of related comments, blogs and social media discussions, highlighted two key issues. The first is the significant attention given to the quantification of changes in patterns of applications for Irish passports, and how these changes are used as a basis for reflection on the changing meaning of Irish citizenship and Irish identity. The second, related topic is the use of these changing patterns of applications for reflection on the nature of Ireland and Irishness, particularly in the aftermath of the Brexit vote. We discuss each of these issues in turn.

\section{New citizenship claims}

Residents of the UK are currently eligible for Irish citizenship and, consequently, Irish passports, in two ways: through the birthright provision of the Good Friday Agreement; or through ancestry. Following the acceptance of the Good Friday Agreement in 1998, Articles 2 and 3 of the Constitution of Ireland, which had asserted territorial and jurisdictional claims over the island of Ireland, were amended. The territorial claim to Northern Ireland was dropped, and it was replaced by - among other provisions - a constitutional right to birthright citizenship for anyone born 'in the island of Ireland'. However, this automatic birthright citizenship only lasted for five years. The 2004 Citizenship Referendum removed this right, and replaced it with a system of citizenship rights that primarily favoured ancestry over residence. ${ }^{1}$ Following the referendum, a person born in the island of Ireland needed to have an Irish citizen parent to automatically qualify for Irish citizenship. However, people born outside Ireland who had an Irish-born grandparent remained eligible for Irish citizenship. ${ }^{2}$

The result of the Brexit referendum vote gave rise to some unintended consequences in relation to Irish citizenship. On the Monday following the vote, some four days later, Northern Irish post offices saw 4,000 enquiries about Irish passports, compared to the usual 200 (Cockburn, 2016). The Guardian reported that 'some post offices in Northern Ireland have already run out of passport applications forms' (O'Carroll \& Marsh, 2016). In August, London's Irish Embassy received 6,710 applications for passports, twice the usual number (Peck, 2016). From June 2016 onwards, there were regular media reports about the significant increase in applications for Irish passports from the UK and Northern Ireland. Table 2 shows the total number of Irish passports issued from 2015 to 2017, with the numbers of applications for Irish passports from Britain and from Northern Ireland in each of these years.

Table 2. Applications for Irish passports from Britain and Northern Ireland, 2015-2017.

\begin{tabular}{cccc}
\hline & Total passports issued & Applications from Britain & Applications from Northern Ireland \\
\hline 2015 & 672,760 & 46,242 & 53,718 \\
2016 & $733,060(+9 \%)$ & $64,996(+40 \%)$ & $67,972(+27 \%)$ \\
2017 & $779,184(+6 \%)$ & $81,287(+25 \%)$ & $81,752(+20 \%)$ \\
\hline
\end{tabular}

Source: Department of Foreign Affairs and Trade Press Releases https://www.dfa.ie/news-and-media/press-releases/pressrelease-archive/2018/january/passport-citizenship-figures-2017/. 
While media reports give conflicting figures, it appears that applications for Irish passports from Britain increased by around $40 \%$ in 2016 and by a further $25 \%$ in 2017 . Applications from Northern Ireland increased by $27 \%$ in 2016 , and by a further $20 \%$ in 2017 (DFA, Carty, 2017). The number of passports issued in 2016 led to a ' $46.74 \mathrm{~m}$ bonanza' for the Department of Foreign Affairs and Trade, with further exaggerated commentary on the increase, such as 'Irish passport applications to top one million post-Brexit' (Irish Examiner, 15 April, 2017). While the increase in passport applications is significant in both Britain and Northern Ireland, it is notable that more passport applications were submitted from Northern Ireland than Britain in the past 3 years, despite a significantly smaller population. ${ }^{3}$

Media reports on applications for Irish passports generally clustered around particular dates. For example, a clustering occurred at the end of each of the two calendar years, apparently associated with a press release from the Department of Foreign Affairs in Ireland. In UK newspapers, the application numbers were occasionally integrated into a broader report on British citizens either looking for EU citizenship or passports, or leaving the UK. A report in The Guardian suggested that at least 17,000 Britons applied for citizenship of another EU state in the year after Brexit, with steep increases in most EU countries (Duncan \& Henley, 2017), while the Independent linked statistics showing rising levels of emigration from the UK with Brexit (Dearden, 2017). Many of the selfstyled 'Brexiles' who spoke to the Independent said that they were leaving Britain because of the attitudes that had become more public during the Brexit campaign, which included racism, ethnocentrism and intolerance (Dearden, 2017). In Irish newspapers, the focus was on applications for Irish passports only, with no reference to the broader trend identified in their UK counterparts.

We note that the phenomenon of applying for an Irish passport became a shorthand for something bigger: on a leading website of NI politics, one writer used the phrase, 'Meanwhile, we're all suddenly carrying Irish passports' (Johnston, 2018), to capture succinctly the social and political shifts occurring in the wake of the Brexit vote. Across both UK and Irish newspapers, there was considerable attention given to prominent media, political and sporting personalities who had applied for, were going to apply for, or who held Irish passports. ${ }^{4}$ A former ambassador and a Conservative MEP from London were among the two people whose decisions came under scrutiny. Sir Ivor Roberts, a diplomat who had worked for the British Foreign Office for 38 years, including a period as British Ambassador to Ireland, applied for an Irish passport on the basis of his Belfast-born father. Roberts said he did this after pressure from his three children, who also wanted to apply for Irish passports. He justified his action by saying that as his family owned a house in Italy, 'I don't want to find myself queuing to get through Rome airport every time I go there' (Morris, 2017). A few months later, Tory MEP for London Charles Tannock obtained an Irish passport on the basis of his Irish-born grandmother. Tannock framed his action as a direct response to Brexit, saying that he 'wanted to distance himself "from shameful aspects of Brexit"' (Irish News, 2017). In doing so, though, he also insisted on the validity of his connections to Ireland. According to Express Online, Tannock said:

I feel more Irish than ever. I am very proud to be Irish. I am going on a pilgrimage with my mother because she has also just got an Irish passport. We are going on a mother and son 
pilgrimage to Dublin in the autumn to try and locate the house where her mother was born in 1895 (in Millar, 2017).

The quotes attributed to Roberts and Tannock represent the two key trends we have identified in media reports that attempt to justify and/or explain the increase in applications for Irish passports. The first, represented by Roberts, is pragmatic cosmopolitanism. National identity is here seen as a fluid category, to be accessed strategically in order to facilitate other lifestyle choices. In the case of Roberts, an Irish passport is a means to bypassing airport security queues in order to move freely between properties in the UK and Italy. Pragmatic cosmopolitanism also underpins the regular guides to EU citizenship published in UK papers, such as the Mirror's overview of how British citizens might keep their EU freedom of movement entitlement after Brexit by applying for other citizenships (Jones, 2017). In response, a column in the Irish Times suggested that 'Many of those seeking a Brexit passport share a major part of contemporary Irish identity: they wish to be European citizens. Ireland has sewn the EU into its fabric, and its future lies in Europe' (Kissane \& Kenny, 2016).

Many pragmatic cosmopolitans make limited or no reference to Irishness, focusing instead on the benefits of a new passport. A Belfast Telegraph columnist stated plainly, 'It's all about convenience and has nothing to do with allegiance' (Edwards, 2017). One commenter on a June 28, 2016 Independent story argued, 'if you want an Irish passport then go and live in Ireland,' to which someone cheerily replied, 'No need! My Irish passport is in the pipeline. Never lived there. Never will' (comments, Cockburn, 2016). The same applicant noted in another comment that s/he in fact had 'two EU citizenship applications in the pipeline.' Another, who applied before the Brexit vote, cited travel convenience and efficiency as one reason for having a second passport was, 'I don't want to be held back on travel because my passport has gone to a visa office' (The Guy, 2016). Danny McManus, a new applicant, similarly wrote on his now-discontinued blog, 'Nomadic Dan,' in September 2016 that 'the very prospect that we would have to apply for a visa every time we planned to take a weekend break in a popular European destination ... is, quite frankly, ridiculous.' Another young man, who had a right to citizenship through his Irish-born father, told the Guardian that, 'I did it to keep my options open, really.... I wanted to make sure I could still move freely around Europe regardless of what happens' (O'Carroll \& Marsh, 2016). Mark Scott, the European technology consultant for the New York Times, wrote of his decision two days after the referendum, acknowledging he was applying despite no real connection to Ireland, simply to maintain the benefits of EU mobility:

those benefits - particularly as a reporter who has lived and worked across the Continent are worth holding on to. And that's why, with a heavy heart, I'm applying to become an Irish citizen, saying goodbye to Britain just as it wants to say goodbye to Europe (Scott, 2016).

If Roberts represents pragmatic cosmopolitans, we argue that Tannock represents the second key trend, that of ethnic apologists. In contrast to pragmatic cosmopolitans, ethnic apologists such as Tannock make reference to their sense of Irishness in order to justify their actions. Tannock claims to feel 'more Irish than ever'. McManus began as a pragmatist, but found his decision led directly to a strengthening of ethnic pride: 
... my new passport strengthened my Irish identity, apart from the traditional Irish music which I have been playing on my fiddle for 22 years and the Irish language which I have been learning for a while and I'm ethnically half Irish as well (though I grew up in the Scottish Highlands) ...

Here, the claim serves to justify the belated discovery of Irish national identity, partly to counter arguments around ethnic authenticity. The competing view - of an essentialised or innate Irish identity - was expressed by celebrity Dermot O'Leary, in an interview in January 2017.

It was never an issue of wrapping yourself up in the Irish flag, but my sister and I were aware of our heritage. ... I've always had an Irish passport and not a British one. It wasn't a gesture, it's just something that happened when I was a kid. (Fox-Leonard, 2017)

The contrast between pragmatic cosmopolitans and ethnic apologists takes on a particular meaning in Northern Ireland. As Table 2 shows, many in Northern Ireland applied for Irish passports in the aftermath of Brexit. They were encouraged to do so by Ian Paisley Jr, a staunch member of the Democratic Unionist Party in Northern Ireland. He tweeted in June 2016: 'My advice is if you are entitled to a second passport then take one... My advice is to take as many as you can, especially if you travel to different world trouble zones' (Irish Independent, 27 June, 2016). A letter-writer to the Belfast Telegraph in October 2017 concurred. S/he wrote that 'For those with dual UK/Irish nationality, it seems pragmatic for our constitutional identity to be whatever we want it to be, as we face an uncertain post-Brexit world' (Belfast Telegraph, 2017).

Yet, this clearly continues to cause anxiety among some in Northern Ireland who identify as unionist. When the Taoiseach, Leo Varadkar, expressed his opinion that unionists and others in Northern Ireland would want to become Irish citizens 'at the very least for convenience', many reacted angrily. DUP politician Gregory Campbell said Varadkar's claims were 'ludicrous and absurd' (in Rainey, 2017). The report continued:

Mr Campbell said Mr Varadkar was implying that the majority of citizens in Northern Ireland would wish to become Irish and this had "no statistical basis". He continued: "He knows that is not the case, to declare the majority are doing so when he has no statistical basis for saying so ...."

The dispute is important, because Campbell insists that an Irish passport has nothing to do with identity. In contrast to pragmatic cosmopolitans who see national identity as fluid, though, Campbell's articulation of identity is essentialist and ethnic. Indeed, Campbell's particular form of pragmatic cosmopolitanism is seen as a bulwark for (unionist) ethnic identity, in contrast to those ethnic apologists - like Charles Tannock - who use their connections to Ireland, however tenuous, to justify their pragmatic cosmopolitanism.

Our focus on newsmedia reports highlights a number of key trends. The first is the extent to which the rise in applications for Irish passports is reported as a factual occurrence, in short articles with no apparent commentary by the author. The second is that feature or opinion articles are considerably fewer and, when included, are more likely to include the viewpoints of people applying for Irish passports. There are some exceptions, such as the contribution by Ronan McCrea, a senior lecturer in Law at University College London. Writing in the Irish Times in August 2016, he commented that, 
Citizenship is fundamental to the collective self-government involved in a democracy. The welfare state is also very dependent on the idea of citizenship.... Such an undertaking is impossible without the shared identity and solidarity that citizenship provides. The value and sustainability of this sense of solidarity risks being undermined if citizenship is granted to large numbers of people with little real connection to the State (McCrea, 2016).

In a Reddit chain response to Niall Flynn's August 2016 op-ed (Flynn, 2016), [hogalot] argued, 'It seems he wants all the benefits of an Irish passport, but none of the pesky responsibilities,' and that under such circumstances, Irish citizenship 'ceases to mean anything,' and is nothing more than 'a triviality.' Another, [temujin64], disputed new applicants' attachment to Ireland: 'If you have the level of affinity towards your Irish heritage that you claim, why weren't you already an Irish citizen before Brexit?' And [pacotes] claimed he knew from his own conversations that the Irishness of some applicants had been completely unknown until recently: 'Most of them had absolutely no idea they were even eligible for one until they found out in the papers during the Brexit shite.' However, these comments are relatively unusual. Clear opposition to British subjects applying for Irish citizenship in either newsmedia or social media was a minority position. Indeed, the experiences of the hosts of the podcast, 'The Irish Passport,' is more representative. They conducted street interviews in Galway city, searching for reluctance to accept the newly passported (https://theirishpassport.com/; episode 8). They found none.

\section{Defining Irishness in uncertain times}

When we speak of citizenship, it is often to invoke the formal status of membership in a nation-state and its attendant rights and privileges, such as suffrage and passports. Citizenship is more fully understood as the relationship between the governor and the governed. The Brexit vote has given rise to a situation where the basic banal right of carrying a passport possesses further, complex meanings that expose the entanglement of the pragmatics and politics of citizenship. A passport application operates here as a signifier of pragmatism and as a political gesture, where even the logistics of the application participate in larger discussions of geopolitics and identity. As Smith's research (2001, 2008) has demonstrated, citizenship must be theorized to recognize the ability of those without legal status to make successful claims, as well as the capacity of emigrants to reach back across borders to leverage their status in places they do not live. In other words, citizenship in practice does not always map directly onto territory. Moreover, dual citizenship does not necessarily weaken or blur identities, but may serve to reinforce both in nuanced ways.

A critical geographical frame for these politics of belonging is thus necessary to understand citizenship as actually practiced. Built on its historically constituted political geographies of the Irish nation, Irish citizenship reflects the complexity of citizenship in practice. While it is far from immune from romantic patriotism, Irish citizenship has strong elements of strategic pragmatism, or 'responsible realism,' as McGarry and O'Leary have characterized consociation in Northern Ireland (2006b, p. 254). These geographies are both actual and virtual (Isin, 2007), and that distinction speaks to how the varying scales of political identities impact individuals (and vice versa). Larger-scale, 'virtual' forces and flows are experienced in 'actual' manifestations: crossing borders, requesting leave to remain, applying for a passport. 
While globalization - generally, and in the specific case of the regionalization of the EUhas detached citizenship somewhat from its traditional geopolitical territories, citizenship has not become meaningless. It is regularly reconfigured in multiple ways at multiple scales, as individuals and families align their personal and political strategies with the logics of capital (Ong, 1999, 2006). Scholars have documented how different political identities may play within and against each other, even within the EU, where some hold multiple passports of member countries, for a variety of personal reasons, not exclusively economic (Studemeyer, 2015); in other circumstances, such the strategic acquisition of US citizenship by birth among non-residents for their children, citizenship is explicitly understood as a means of access to political and economic resources (Balta \& Altan-Olcay, 2016).

Under the GFA, the border between NI and the Republic was discursively reconfigured to allow Irish citizenship to be geographically grounded in two territories. This created a social and political space for British and Irish identities and the national aspirations they represented to co-exist in one polity. Definitions of Irishness remained complex, but for the most part were not conflictual amongst themselves, and the tense distinction between British and Irish as a defining feature of Irishness was muted.

A renewal of these tensions is visible in the newsmedia and social media discussions of Irish passport applications following the Brexit vote. Faced with restrictions on their EU mobility and uncertainty regarding their status within the UK, those with claims to Irish citizenship through residence in Northern Ireland or through their ancestry are strategically choosing security. While some are comfortable with the pragmatics of the choice, many others seek to justify their decision to apply through highlighting the significance of childhood memories, a desire to reconnect with their family roots, or a generalized 'pride' in their connection to Ireland. Still others are challenging the applicants, arguing that they do not have a 'real' connection to Ireland. Citizenship remains strategic, as individuals and communities navigate changing and still-uncertain circumstances.

Romanticized narratives of belonging, of experiential or essential Irishness, are being raised by applicants and by their critics. The newsmedia's breathless daily coverage of the numbers of passport applications over several months, particularly in the Irish media where coverage was notably greater, placed the impact of these newly minted Irish citizens on the constitution of the Irish nation in the spotlight. What indeed will constitute 'Ireland'-as territory, nation, or discursive object-in five or ten years' time? Who will be 'Irish'? To understand the specific situation of the island of Ireland, as well as citizenship in the shifting geopolitics of the early twenty-first century more broadly, requires a critical reading of public discourse and recognition of the strategy and dynamism of practices of belonging. The myriad and as-yet-unresolved consequences of Brexit for the Irish economies, the island's politics, the peace process and the land border have produced, with the assistance of both the media and the limited engagement of Westminster, a state of uncertainty which individuals seek to stabilize. The Brexit vote and ongoing negotiations have thus put ideas and practices of citizenship in new motion, and the effects have only begun to unfold.

\section{Notes}

1. Changes to citizenship were a response to a moral panic over 'citizenship tourism', with the result that citizenship became more difficult to obtain for immigrants living in Ireland (Gilmartin, 2015, pp. 132-138). 
2. This is made explicit in the Foreign Births Register, which provides access to Irish citizenship for people born outside Ireland, but with a grandparent who was born in Ireland, or a parent who was an Irish citizen at the time of birth. Though intended to encourage the descendants of Irish emigrants to return to Ireland, only 16,500 people were granted Irish citizenship by descent from 1936 to 1986 (Daly, 2001, p. 403).

3. The population of Britain, at around 63 million, is over 30 times that of Northern Ireland (around 1.8 million).

4. Among those highlighted were media personalities Dermot O'Leary and Stephen Nolan, model Stella Maxwell, writer Nick Laird, actor Anna Friel, and soccer player Scott Hogan.

\section{Disclosure statement}

No potential conflict of interest was reported by the authors.

\section{Notes on contributors}

Patricia Burke Wood is Professor of Geography at York University, Canada. She studies citizenship and practices of democracy, and their relationships to identity and attachment to place.

Mary Gilmartin is Professor of Geography at Maynooth University, Ireland. She studies migration, mobilities and belonging.

\section{ORCID}

Patricia Burke Wood (D) http://orcid.org/0000-0002-2715-0426

\section{References}

Balta, E., \& Altan-Olcay, Ö. (2016). Strategic citizens of America: Transnational inequalities and transformation of citizenship. Ethnic and Racial Studies, 39(6), 939-957.

Becker, S. O., Fetzer, T., \& Novy, D. (2017). Who voted for Brexit? A comprehensive district-level analysis. Economic Policy, 32(92), 601-650.

Belfast Telegraph. (2017). Letter: People will pick when to be British or Irish. 25 October.

Carty, E. (2017). Irish passports demand hits new record. Irish News, 5 January.

Cassidy, K., Innocenti, P., \& Bürkner, H.-J. (2018, August). Brexit and new autochthonic politics of belonging. Space and Polity. doi:10.1080/13562576.2018.1505490

Cockburn, H. (2016). Ireland urges Britons to stop applying for Irish passports after Brexit. Independent, 28 June.

Cronin, M. (2003). Projecting the nation through sport and culture: Ireland, Aonach Tailteann and the Irish Free State, 1924-32. Journal of Contemporary History, 38(3), 395-411. Retrieved from http://www.jstor.org/stable/

Daly, M. (2001). Irish nationality and citizenship since 1922. Irish Historical Studies, 32(127), 377407.

Dearden, L. (2017). 'I don't recognise my country anymore': British citizens leaving UK because of Brexit amid exodus of Europeans. Independent, 26 August.

Downing, J. (2017). Monday Interview: Peace process is central to Brexit talks - Hogan. Irish Independent, 9 January.

Duncan, P., \& Henley, J. (2017). Brexit vote creates surge in EU citizenship applications. The Guardian, 13 October.

Edwards, R. D. (2017). Second passport doesn't have to mean a change in your national identity. Belfast Telegraph. October 30.

Flynn, N. (2016). After Brexit: Why I want to apply for an Irish passport. Irish Times, August 25. 
Fox-Leonard, B. (2017). Dermot O'Leary: 'I missed out on some great relationships because I was obsessed with work'. Telegraph, 23 January.

Gilmartin, M. (2015). Ireland and migration in the twenty-first century. Manchester: Manchester University Press.

Goodwin, M. J., \& Heath, O. (2016). The 2016 referendum, Brexit and the left behind: An aggregate-level analysis of the result. The Political Quarterly, 87(3), 323-332.

The Guy. (2016). Applying for an Irish passport and why I did. Flights and Frustration blog, 26 February. Retrieved from http://flightsandfrustration.com/applying-for-an-irish-passport-andwhy-i-did/

Harding, L. (2016). Brexit vote sparks scramble for European passports. The Guardian, June 24.

Hayward, K. (2010). European stories as national narratives: Irish intellectuals on Europe. In J. Lacroix, \& K. Nicolaidis (Eds.), European stories: Intellectual debates on Europe in national contexts (pp. 167-182). London: Oxford University Press.

Hayward, K. (2018, August). The pivotal position of the Irish border in the UK's withdrawal from the European Union. Space and Polity. doi:10.1080/13562576.2018.1505491

Hepp, A., \& Krotz, F. (2014). Mediatized worlds: Culture and society in a media Age. Basingstoke: Palgrave Macmillan.

HM Government. (2017). The United Kingdom's Exit from and Partnership with the EU. Retrieved from https://www.gov.uk/government/uploads/system/uploads/attachment_data/file/589191/ The_United_Kingdoms_exit_from_and_partnership_with_the_EU_Web.pdf

Hunt, T. (2015). 'In our case, it seems obvious the British organising committee piped the tune': The campaign for recognition of 'Ireland' in the olympic movement, 1935-1956. Sport in Society, 18 (7), 835-852.

Irish Examiner. (2017). Irish passport applications to top one million post-Brexit. 15 April.

Irish Independent. (2016). Rush for Irish passports as Paisley advises getting one. 27 June.

Irish News. (2017). Tory MEP 'Remainer' gets Irish passport. 6 September.

Isin, E. F. (2007). City.State: Critique of scalar thought. Citizenship Studies, 11(2), 211-228.

Johnston, C. (2018). Let's stop rearranging the border deckchairs. Slugger O’Toole blog, 17 February. Retrieved from https://sluggerotoole.com/2018/02/17/lets-stop-rearranging-the-borderdeckchairs/

Jones, S. (2017). British and want to stay European? Here is how to keep your EU citizenship after Brexit. Mirror, 29 March.

Kissane, C., \& Kenny, D. (2016). Do we really want to give Irish passports to all these Brits? Irish Times. July 28.

Laffan, B., \& O'Mahony, J. (2008). Ireland and the European Union. Basingstoke: Palgrave and MacMillan.

McCrea, R. (2016). We grant Irish passports to British citizens at our peril. Irish Times. August 8.

McGarry, J., \& O'Leary, B. (2006a). Consociational theory, Northern Ireland's conflict, and its agreement. Part 1: What consociationalists Can learn from Northern Ireland. Government and Opposition, 41(1), 43-63.

McGarry, J., \& O'Leary, B. (2006b). Consociational theory, Northern Ireland's conflict, and its agreement. 2. What critics of consociation Can learn from Northern Ireland. Government and Opposition, 41(2), 249-277.

Millar, J. (2017). 'I am ashamed to be British.' Remainer MEP becomes Irish citizen due to Brexit. Express Online, 4 September.

Morris, A. (2017). Politics - Ex-ambassador gets Irish passport. Irish News, 2 May.

O'Carroll, L., \& Marsh, S. (2016). Readers explain why they are rushing for dual-nationality EU passports. Guardian, 27 June.

Ong, A. (1999). Flexible citizenship: The cultural logics of transnationality. Durham, NC: Duke University Press.

Ong, A. (2006). Mutations in citizenship. Theory, Culture, and Society, 23(3), 499-505.

Peck, T. (2016). MPs are applying for Irish passports after Brexit. Independent, 29 September.

Rainey, A. (2017). Anger after Varadkar says most Northern Ireland people will wish to be Irish after Brexit. Belfast Telegraph, 23 October. 
Reuters. (2017). Barnier reassures Ireland that EU stands with Dublin on Brexit. November 24. Retrieved from https://uk.reuters.com/article/uk-britain-eu-ireland-barnier/barnier-reassuresireland-eu-stands-with-dublin-on-brexit-idUKKBN1DO1EE

Ryan, B. (2001). The common travel area between Britain and Ireland. Modern Law Review, 64(6), 831-874.

Scott, M. (2016). Why I'm choosing to become an Irish citizen. New York Times, 25 June.

Smith, M. P. (2001). Transnational urbanism: Locating globalization. London: Blackwell.

Smith, M. P. (2008). Citizenship across borders. Ithaca, NY: Cornell University Press.

Smyth, P. (2018). More than $90 \%$ of Irish people want to stay in EU, poll reveals. Irish Times, May 8. Studemeyer, Catherine Cottrell. (2015). Geographies of flexible citizenship. Geography Compass, 9 (10), 565-576.

Waisbord, S., ed. (2014). Media sociology: A reappraisal. Cambridge: Polity Press. 